\title{
Look but don't touch! An alternative to the gold standard?
}

\author{
Max Baghai, PhD, FRCS(C-Th), and Lindsay C. H. John, MD, FRCS(C-Th)
}

\author{
From the Cardiac Surgery Department, Kings College Hospital, London, United Kingdom. \\ Disclosures: Authors have nothing to disclose with regard to commercial support. \\ Received for publication March 23, 2017; revisions received March 27, 2017; accepted for publication April 4, \\ 2017; available ahead of print May 4, 2017. \\ Address for reprints: Max Baghai, PhD, FRCS(C-Th), Kings College Hospital, Denmark Hill, London SE5 9RS, \\ United Kingdom (E-mail: mbaghai@nhs.net). \\ J Thorac Cardiovasc Surg 2017;154:467-8 \\ 0022-5223/ $\$ 36.00$ \\ Copyright (C) 2017 by The American Association for Thoracic Surgery \\ http://dx.doi.org/10.1016/j.jtcvs.2017.04.007
}

The clinical evidence for the superiority of the left internal thoracic artery as a conduit for grafting the left anterior descending coronary artery with respect to patency and improved survival is well established. ${ }^{1,2}$ As such, the Society of Thoracic Surgeons has made the use of this conduit a quality issue. ${ }^{3}$ In their article in this issue of the Journal, Samano and colleagues ${ }^{4}$ have asked the question of whether the use of saphenous vein harvested with the no-touch technique is a good alternative when the left internal thoracic artery is unsuitable. Although the left internal thoracic artery is now by far the most commonly used conduit to bypass the left anterior descending artery, most series suggest that it is not used in approximately $5 \%$ of cases. The potential causes for its not being used include damage during harvest, poor flow, or other concerns about its quality. It may also not be used when there are concerns about increased morbidity in patients who are unlikely to benefit from its superior long-term patency. The no-touch saphenous vein technique, in which the vein is harvested with a pedicle and is not distended, is an attempt to minimize damage and thereby improve long-term patency. Limited published results to date are encouraging. ${ }^{4,5}$ Samano and colleagues ${ }^{4}$ are long-term users of this technique. They have retrospectively looked at their patients who received no-touch saphenous vein as a graft to the left anterior descending artery. In the 91 patients who were available to undergo computed tomographic angiography, 95.6\% (87/91) of the no-touch saphenous vein grafts to the left anterior descending artery were patent at a mean of 6 years after implantation. As Samano and colleagues ${ }^{4}$ point out, this is comparable to the reported patency of the left internal thoracic artery. Their primary conclusion was that if for any reason the left internal thoracic artery is not appropriate for use, then the notouch venous graft can be considered as a potential good alternative.

A strength of this study is the relatively objective measure of patency in their study group, which used computed tomographic angiography rather than clinical end points. Its limitations are clearly discussed by

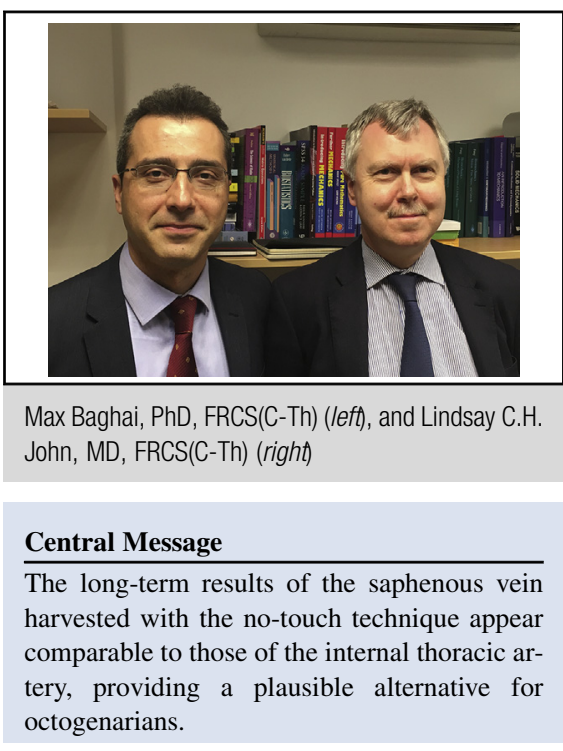

See Article page 457.

Samano and colleagues. ${ }^{4}$ It is a small observational cohort trial with possible selection bias. Of the original 168 patients, 71 were unavailable for follow-up, and these included 34 who had died. Despite the impressive patency figures, it would be unreasonable to extrapolate beyond the conclusions of Samano and colleagues ${ }^{4}$ themselves that saphenous vein harvested with the no-touch technique can be considered as an alternative to the left internal thoracic artery when the use of the latter is inappropriate.

A secondary aim of this study was to compare the patencies of no-touch saphenous vein grafts to the left anterior descending artery with those at different sites. They demonstrated no significant difference. This is additional evidence for the efficacy of the saphenous vein harvested by the no-touch method. The limitations of the study, however, preclude conclusions stronger than this. As Samano and colleagues ${ }^{4}$ suggest, a large-scale prospective trial of the use of no-touch saphenous vein grafts may be appropriate and would be necessary to prove that it is more than just a promising alternative. Samano and colleagues ${ }^{4}$ are to be congratulated on their perseverance with this technique, because it has clearly demonstrated improved patency rates relative to previously published data.

With the advent of total arterial revascularization and advances made by complex percutaneous coronary 
interventions, including the recent trials on patients with left main stem disease, it is refreshing to see the saphenous vein doing well. The main argument that cardiologists have for hybrid revascularization is that less optimal outcomes are seen with surgery with the non-LAD targets. This is less true with complete arterial revascularization, but now the no-touch technique may allow the saphenous vein to get back in the ring. Those institutions running an endoscopic vein harvesting program may find it difficult to emulate this technique, but it may still be possible with the bridge technique, especially with the aid of preoperative ultrasonographically guided vein mapping. Bespoke surgical revascularization is now a reality, and as surgeons maybe all we really need to do is just start respecting the vein a little bit more.

\section{References}

1. Leavitt BJ, O'Connor GT, Olmstead EM, Morton JR, Maloney CT, Dacey LJ, et al. Use of the internal mammary artery graft and in-hospital mortality and other adverse outcomes associated with coronary artery bypass surgery. Circulation. 2001; 103:507-12.

2. Lytle BW, Loop FD, Cosgrove DM, Ratliff NB, Easley K, Taylor PC. Long-term (5 to 12 years) serial studies of internal mammary artery and saphenous vein coronary bypass grafts. J Thorac Cardiovasc Surg. 1985;89:248-58.

3. ElBardissi AW, Aranki SF, Sheng S, O'Brien SM, Greenberg CC, Gammie JS Trends in isolated coronary artery bypass grafting: an analysis of the Society of Thoracic Surgeons adult cardiac surgery database. J Thorac Cardiovasc Surg. 2012;143:273-81.

4. Samano N, Geijer H, Liden M, Fremes S, Bodin L, Souza D. The no-touch saphenous vein for coronary artery bypass grafting maintains a patency, after 16 years, comparable to the left internal thoracic artery: a randomized trial. J Thorac Cardiovasc Surg. 2015;150:880-8.

5. Souza DS, Johansson B, Bojö L, Karlsson R, Geijer H, Filbey D, et al. Harvesting the saphenous vein with surrounding tissue for CABG provides long-term graft patency comparable to the left internal thoracic artery: results of a randomized longitudinal trial. J Thorac Cardiovasc Surg. 2006;132:373-8. 